\title{
A quest for identity in Zora Neal Hurston's Their Eyes Were Watching God
}

\section{Zahra Mahdian Fard, Bahman Zarrinjooee}

Department of English Language and Literature, College of Humanities, Boroujerd Branch, Islamic Azad University, Boroujerd, Iran

\section{Email address:}

Mahdian.rose@gmail.com (Z. Mahdian Fard), bahmanzarrinjooee@yahoo.com (B. Zarrinjooee)

\section{To cite this article:}

Zahra Mahdian Fard, Bahman Zarrinjooee. A Quest for Identity in Zora Neal Hurston's Their Eyes Were Watching God. International Journal of Literature and Arts. Vol. 2, No. 4, 2014, pp. 92-97. doi: 10.11648/j.ijla.20140204.12

\begin{abstract}
Identity or the preoccupation with one's self constitutes one of the main obsessions of Zora Neale Hurston (1891-1960) as a novelist. The fundamental argument in this paper is the quest for identity in Hurston's Their Eyes Were Watching God (1937). She portrays characters who try to recognize themselves based on their own inner desires and thoughts. Many signs and hints in the novel demonstrate the main character's notion of selfhood and identity changes as she is exposed to the new conditions, realities and experiences. At the end of Janie's journey, she turns into an integrated and self-aware individual through a psychological process. Theoretically, this paper applies Frantz Fanon's (1925-1961) theories, who dealt with psychological impacts of colonialism on the colonized people. Concerning his critique of the White's oppression on black people, Fanon focuses his argument on the inadequacy of European rationalism and their disregard of the experience of 'the other.' For him colonization is totally a Euro- or White-centered discourse which does not account for or include non-White and non-European discourses. Fanon asserts that black people need to free themselves from the hegemony of White people and become independent. Eventually, this paper shows that Janie in Their Eyes Were Watching God, after all her attempts and search for self-realization or her feminine identity, gains a great success in achieving her goals.
\end{abstract}

Keywords: Identity, Black, Oppression, Colonialism, Self-realization

\section{Introduction}

Identity includes both a person who sees him/herself and those who see themselves. It is related to one's eyes or others' eyes both connected to the way watching and seeing. Postcolonialism as an academic approach to literary criticism revolves around this fundamental value that the identity of Black people has been oppressed throughout history. The recognition of Black people as normal human beings who can be identified as possessing self or identity is the major outcome of postcolonial discourse. According to Fanon (1925-1961), "identity is never an a priori, nor a finished product; it is only the problematic process of access to an 'image' of totality" (2008: xxix).

Zora Neal Hurston (1891-1960) is one the famous African-American writers who was born in Eatonville, which is the setting for most of her fictions. The choice of Eatonville as the setting of Their Eyes Were Watching God might be considered as a deliberate and political act on the part of Hurston which can be connected to the way Hurston considers white-black crisis. Hurston published her first story in 1921 that was recognized by Harlem Renaissance writers. Jonah's Gourd Vine is Hurston's first novel which she published in 1934. Then Mules and Men appeared. Hurston wrote Their Eyes Were Watching God in 49 days.

Their Eyes Were Watching God was published in 1973. Not only is this novel appreciated by African-American for its rich Black culture and dialect, it is also of interest to a wide range of feminists because of females' self-awareness. Their Eyes Were Watching God can be related to Hurston's political understanding of the notion of blackness and female-ness as well. Concerning Hurston's protagonist's quest for her own self and identity in Their Eyes Were Watching God, it can be reasserted that from the very beginning up to the last sentence of the novel Janie's selfhood undergoes a lot of changes and transformations.

\section{Identity in Nanny, Joe, Janie}

Identity or the sense of selfhood has been one of the most complicated and ever developing notions in literary and critical studies. It continues to become an obsession of 
critics, novelists and scholars. Terms such as man, woman, body, self, person, individual, I, subject, and human, all have been repeatedly used in literary and critical discussions to refer to the identity of a certain person belonging to a particular community or tradition.

Early considerations of the notion of identity dated back to ancient time, in the fourth century BC. The seventeenth century French philosopher Rene Descartes famously claimed that "I think, therefore I am" (24), which transformed the discussions and definitions about selfhood and identity. For the first time in history individual turned into the main source of meaning as well as the criterion for assessing and evaluating life and the living: "The Cogito or the thinking self was the base of what mankind could achieve in their life" (Rivkin and Rayne 389). This self or identity seemed to be untouched by external socio-political or internal psychic dimensions which might have an impact or influence on it in one way or another. This individual was the white European man. Etienne Balibar explains:

The core of the representation of Man as the 'foundation' of his own thoughts, actions and history, has, for three centuries at least, not been simply a valorization of human individuality and the human species as the bearer of the universal, it has been the representation of Man as the subject. The essence of humanity, of being a human, which should be present, both in the universality of the species and in the singularity of the individual, both as a reality and as a norm or a possibility, is subjectivity. (Balibar3-4)

Accordingly, the consciousness and awareness about identity and self became one major topic and humanity was defined in a new way as a "possibility" and a "norm." Hans Bertens' reading of the Enlightenment understanding of self reveals a number of shortcomings of this consideration of selfhood:

For about three centuries modern European philosophy became involved with the question of self and subjectivity. Humanity became a major topic for literary and philosophical fantasies which examined man as a selfsufficient, independent and knowable entity. But what is needed to be recapitulated at this point is that even in seventeenth century and Enlightenment period major thinkers fell prey to some restraining and highly trapping factors such as history, masters, slaves, proletariat, nation, society, and utopia and so on. Instead of dealing head on with self and individual, Marx divided the world into labor class and capitalist class, on the other hand, Hegel, another major philosopher in eighteenth century Europe, divided the world into Masters and Slaves. Though highly influential their thoughts and explorations were, Hegel, Marx and Engels produced a class conscious, groupconscious individuals at best. This polarization and dichotomization of social sphere and the historicization of self, although brought about a new conflict-informed sociopolitical understanding of man, sacrificed individual and self for much larger and more powerful entities called race, class, and nation and so on. (Bertens 79-80)

In early and mid-nineteenth century after the demise of monarchy which coincided with the rise of capitalism the interest in identity and individuality is intensified. Capitalist primary motto was defined as: "you are what you own" (Tyson 47). Therefore capitalism once again defined individual and identity to include new considerations. Early in the twentieth century Sigmund Freud (1856-1939) the Austrian psychoanalyst changed the discussions concerning identity and self-hood. Throughout his subsequent publications, he further elaborated on the complexity and inaccessibility of human mind. Before Freud's critical examinations of the human psyche which led to the inauguration of psychoanalysis as a powerful academic and literary approach, mind was predominately defined as a place where the rational and thinking "Cogito" existed (Bressler 144).

In mid-twentieth century, for instance, feminism challenged the male-dominated and patriarchal understanding of identity which excluded the experience of women. The result of this challenge was the recognition of female self. Feminists argue that the identity of women has been silenced by the patriarchal societies from ancient time up to the present time.

Another example of new understanding of self is the challenge of colonial discourse by the black people which led to the postcolonial understanding of identity.

In Hurston's Their Eyes Were Watching God characters such as Nanny, Joe and Janie are individuals who look for self-realization. Nanny's calculated talking about her own past and the way whites treated her daughter and even herself manifest her inner involvement with black identity. Nanny's main method and technique for raising awareness about black identity is to tell her own story to her granddaughter. This technique of orally recounting one's life story is among the main techniques in postcolonial novels. Below Nanny tells her story to Janie to influence and galvanize her fight against white people:

You know, honey, us colored folks is branches without roots and that makes things come round in queer ways. Ah was born back due in slavery so it wasn't for me to fulfill my dreams. You can't baet nobody down so low till you rob 'em of they will. Ah didn't want to be used for a work-ox and a brood-saw. Ah wanted to preach a great sermon about colored people sittin' on high but wasn't no pulpit for me. Freedom found me wid a baby daughter in mah arms. Ah knowed here you was in de world. ( $E W G 28$ )

Nanny speaks in a way which indicates that she is totally self-preoccupied with black woman; she knows the real situation of Black people in a society which is dominated by the Whites. She imagines herself as a powerful leader who is preaching to the slaves and other dominated groups about the joy of being independent and free person who is under the control of his identity. What is striking about Nanny's stories is that she recounts them in a way which further emphasizes Black agency and self-construction; whenever she speaks she attacks the Whites' wrongdoings and evils done to the Blacks.

Janie's words also demonstrate that from early childhood 
she is a girl who, to a great extent, tries to fashion her own blackness rather than to conceal it. Her famous phrase is "Where is me? Ah Don't see me" or her "Aw, Aw! Ah'm colored" $(E W G 24)$. What is highly significant about this statement is that it reveals a great deal about Janie's character. Words such as "me"and "Ah" which have been repeated three times in a short sentence show that she is extremely in favor of her own identity as a Black girl. Immediately after that short sentence she uses the word "colored" which introduces her as a black female. This sense of knowing her own self and announcing it in a clear way continues as the narrative focuses on Janie's experiences.

Another character who shares similar tendencies with Nanny and Janie is Joe Starks: "Mostly he talked about plans for the town when he got there," "Ah'm buyin'in here, and buyin' in big" (EWG39, 40). His main ideal or life work is to build a city in which just colored people will inhabit; this ideal desire reveals that Joe is passionately struggling to make black community aware of their identity. For him becoming independent and separated from the whites constitutes the only practical and viable remedy for black people. Therefore these three characters might be regarded as representing Fanonian world view which emphasizes independence, self-construction, selfrealization and identity.

\section{Janie's Quest for Identity}

From the first pages of the novel the reader does not know the name of main female character of the novel; she is simply referred to as woman which indicates that she is still an abstract and obscure entity without any particularity for the reader. Now Janie has returned to Eatonville nearly two years after Joe Starks' death and some few months after Tea Cake's with whom she last time left Eatonville. Her neighborhood women are full of questions and hostility towards her and for this reason they still call "Janie Starks" (EWG 19). In her evening conversation with Phoebe she tells her the story of her life from her early childhood up to this moment when she returned to Eatonville. Janie begins with expressing her anger and contempt for female community in Eatonville those who witnessed her return to this place:

So long as they get a name to gnaw on they don't care whose it is, and what about 'specially if they can make it sound like evil. If they wants to see and know, why they do n't come kiss and be kissed? Ah could then sit down and tell 'em things. Delegate Ah been a to de big 'ssociation of life. Yessuh! De big convention of livin' is where Ah been dis year and a half y' all ain't seen me. ( $E W G 22)$

Based on above quotation, after moving away from Eatonville Janie changes a lot and considers herself a different person or self from these women. Another equally important aspect which Janie refers to is her implicit attack on talking or telling. She seems to consider that mere telling will not amount to anything valuable if it is not accompanied by some other particularities. These other particularities will become more evident as Janie's story continues. Janie's 'If they want to see and know' is another noteworthy phrase as she retrospectively proceeds to recount and reveal the story of her life. In this phrase after using the verb 'see' she uses the verb 'know.' This way of speaking is predominant in Janie's speech, which communicates much about her stand about life. Janie goes on after a short pause saying that: 'Naw, 'tain'tnothin' lak you might think. So 'tain't no use in me telling Yousomthin' unless Ah give you de understandin' to go 'long wid it. Unless you see the fur, a mink skin ain't no different from a coon hide. Lookaheah, Phoebe" (EWG 23).

Once again Janie emphasizes the verb 'see' and connects it to the word 'understanding.' For her there is no understanding without first "see-ing" the object or the notion to be understood. Once more she repeats the verb "tell" and exposes its inadequacy if it is not matched with 'see.' This aspect of Janie's character which is the constant part of the question of her identity will be examined in more details. She immediately begins to recount her early childhood experience to Phoebe; telling her that she has not 'seen' her mother and father and that she spent much of her childhood life in West Florida, the house Mrs. Washburn, a white woman, where her grandmother, Nanny, worked as a housemaid to this white family:

Ah was widdem white childun so much till Ah didn't know Ah wuzn't white till Ah was round six years old. Wouldn't have found it out then, but a man come long takin pictures and without askin' anybody [...] Round a week later de man brought de pictures for Mis' Washburn to see and pay him which she did. So when we looked at de picture and everybody got pointed out there wasn't nobody left except a real dark little girl with long hair standing by Eleanor.Dat's where Ah wuzs'posed to be, but Ah could n't recognize dat dark chile as me. So Ah ast, 'where is me? Ah don't see me. (EWG 24)

Aside from invoking the metaphor of 'see' through taking the picture of these children as well as through watching those taken photos, the narrator of the story draws our attention to Janie and how she was not conscious of her blackness before she was six years old. Before this scene or incident Janie considered herself a normal child among other white children, her identity was unconsciously defined by her through her sameness with other white children. This visual image which is based on her skin color divides her from white children; from now on she knows that she is a black girl. Ironically enough she comes to 'know' herself through watching and 'see-ing' herself. This is the earliest moment of self-recognition for Janie which is uncontrollably black recognition in essence. Another point is that from very early childhood Janie is conscious about her own self and identity; as the experience of looking at the picture shows she is looking for her image or picture and tries to find herself to 'see' what she looks like. The short sentence "where is me" (EWG 24) demonstrates Janie's restlessness to find and see herself. 
It is noteworthy to see how Miss Nellie reacts to Janie's inability to see herself in the picture: "Everybody laughed, even Mr. Washburn. Miss Nellie, de mama of de chillun said, 'Dat's you, Alphabet, don't you know yo' own self?" (EWG 24). The experience of being laughed at in front of one's peers, as well as being named "Alphabet" rather than being called by one's proper name, can be devastating event for a six-year-old girl. Most importantly, Miss Nellie emphasizes Janie's blackness and lack of name in a way which abandons Janie of any interiority and self. Miss Nellie introduces the word "self" through the verb "know" implying that blackness is immediately recognizable; she wonders why Janie does not know this white presupposition. A moment later, Janie utters, "Aw, aw! Ah'm colored!" (EWG 24), which is one of the most significant short sentences in Their Eyes Were Watching God, and might be considered as a moment when Janie reaches a sort of recognition of both her blackness and selfhood. This recognition as a black girl is external, because white people define her as different based on her external skin features.

Fanon argues that identity is a socio-economical phenomenon rather than being an internal one. From this moment onwards in the life of Janie she becomes aware of identity as a black girl who is different from the white girls in her surroundings. Certainly her Nanny is cute enough to know Janie's new understanding of her new 'self' and identity that she attempts to move away from the house of Washburn family. After this painful experience Janie's selfawareness as a black girl increases and "sees" her blackness more than ever: 'Us lived dere havin' fun till de chillun at school got to teasin' me 'bout livin' in de white folks' back-yard" (EWG 24).

After passing of seven or eight years Janie reaches a stage in her life when she experiences internal transformations within herself. It is spring time in West Florida that Janie spends most of the day under a blossoming pear tree in the backyard:

That was to say, ever since the first tiny bloom had opened. It had called her to come and gaze on a mystery. From the leaf-buds to snowy virginity of bloom; It stirs her tremendously. How? Why? What? Why? The rose of the world was breathing out smell. It connected itself with other vaguely felt matters that had struck her outside observation and buried themselves in her flesh. (EWG 25)

This quotation is one example of the character's undergoing inner changes and ambiguities concerning the way she is supposed to see the world around her. At this stage Janie is still unable to communicate what she is looking for. She is full of questions and inner conflicts. But interestingly enough the narrator once again uses the verb which is similar to "see": "to gaze" (EWG 25). An inner unknown force has called upon her to "gaze" at a "mystery" $(E W G 25)$. Janie is characterized as a person who gazes at the world. Still the inner desire is expressed through a metaphoric language.

Such phrases "a pear tree in blossom," "visiting bees," "tree soaking" and "bursting buds" ( $E W G$ 25) show that now Janie is turning into a new person whose desire for love and be loved, to see and be seen manifests itself through these visual images. Now she is no longer "blind" and sees things vividly; her first sensual and brief attachment with Johnny Taylor is a good indication of the rise of a new consciousness in her. As the narrator puts it: "That was the end of her childhood" ( $E W G 25)$.

Janie resorts to poetic language to deal with her inner desires. At this stage her identity or her 'self' is quite ambiguous since she does not know what she really desires. This poetic language and ambiguous phrasing continues till she becomes acquainted with Joe Starks; his marriage proposal and their subsequent marriage together put Janie in another phase of her search for her "self." In both marriages Janie's ability to hurt her husbands is equal to their ability to hurt her. As her marriage to Jody deteriorates she begins to observe herself: "one day she sat and watched the shadows of herself going about tending store and prostrating itself before Jody, while all the time she herself sat under a shady tree with the wind blowing through her hair and her clothes" (EWG 68).

Immediately after Jody's death she goes to the looking glass where she told herself to wait for her, and there she discovers that a handsome woman has taken her place. She tears off the kerchief Jody has forced her to wear and lets down her plentiful hair: "The weight, the length, the glory was there. She took careful stock of herself, then combed her hair and tied it back up again" ( $E W G$ 75). One can approach and examine it as Janie's deliberate attempt to fashion and praise black female self and a sense of self love or narcissism on the part of a black female. This black female refers to herself through words such as 'handsome,' and 'glory.' Janie's forceful and powerful character is vividly shown in them. What is even more noteworthy is that Janie has learnt to look at herself, to see herself. To see is to love, to praise, to know one's self and even others. Janie has acquired the power to see, to enjoy and to understand, in this case her own self which can be a female black self and a female self or rather loosely herself as a human removed from femaleness or blackness. As Mary Helen Washington asserts:

In her first moment of independence Janie is not seen as autonomous subject but again as visual object, "seeing herself seeing herself," draping before herself that "hidden mystery" that attracts men and makes her superior to women. Note that when she turns to the mirror, it is not to experience her own sensual pleasure in her hair. She does not tell us how her hair felt to her-did it tingle at the roots? Did she shiver with delight?-no, she takes stock of herself, makes an assessment of herself. What's in the mirror that she cannot experience without it: that imaginary other that the mirror represents, looking on in judgment, recording, not her own sensations but the way others see her. In the long paragraph that tells us how she has changed in the six months after Jody's death, we are told that Janie talked and laughed in the store at times and was happy except for the 
store. (13)

The much-celebrated description of Janie's discovery of her split selves: "She had an inside and an outside now and suddenly she knew how not to mix them" represents her internal life as divided between two men: her outside self exists for Joe and her inside self she is "saving up" for "some man she had never seen" (EWG 65). This major transformation in Janie's character suggests that her 'self' is further developing and changing in the course of the turn of the events. Now she acquires a new understanding and knowledge of her own identity as a woman and also now she appreciates the nature of love and human relationship in a new light. In fact, Janie in her first two marriages did not act as the agent of what she internally desires; rather she was half active in deciding to marry Killicks and Joe Starks. In contrast, her third and final marriage to Tea Cake indicated her full awareness and presence in the process of decision making and the sense of her own agency to accept Tea Cake' marriage proposal. At this point in her life and the turn of events Janie has changed a lot and has become a new person who can decide her own life and fate. This moment is significant for her since it represents a moment when she is freed from patriarchal dictation of its rules and regulations. As Harold Bloom says:

Power in Hurston is always potentia, the demand for life, for more life. Despite the differences in temperament, Hurston has affinities both with Dreiser and with Lawrence, heroic vitalists. What is strongest in Janie is a persistence akin to Dreiser's Carrie and Lawrence's Ursula and Gudrun, a drive to survive in one's own fashion. Nietzsche's vitalistic injunction, that we must try to live as though it were morning, is the implicit basis of Hurston's true religion, which in its American formulation (Thoreau's), reminds us that only that day dawns to which we are alive. (4)

The force of her own "vitalism" forces Janie to kill him in self-defense, thus ending necessarily life and love in the name of the "possibility of more life" again (ibid). Here it is in accordance with Hurston's famous remark in response to Carl Van Vechten's photographs which establish her character as a "vitalist": "I love myself when I am laughing. And, then again when I am looking mean and impressive" (ibid). As Washington, in her essay "Zora Neal Hurston's Emergent Female Hero," argues "if the end of the romantic heroine is marriage, then Hurston has certainly resisted the norms of romance by having Janie kill Tea Cake so the narrative resolves itself in the repression of romance and the reassertion of quest," the result is a plot that is highly critical of those male-defined rules and regulations that control women and deny them a "role outside of the boundaries of patriarchy" (18).

Finally while Janie's culture honors the oral art, "this picture making with words," Janie's final words in Their Eyes Were Watching God show:

Talkin' don't amunttuh uh hill uh beans when you can't do nothing else [...] Pheoby you got tuh go there tuh know there. Yo papa and yo' mamma and nobody else can't tell yuh and show yuh. Two things everybody's got tuh do fuhtheyselves. They got tuh go tuh Go d, and they got tuh find out about livin' fur theyselves. ( $E W G$ 142)

In this conversation, Janie seems to justify her many times repeated moments of silences and lack of voice in the novel. On the one hand, Janie can best be characterized as a person who is not in favor of talking. Characteristically, Janie advocates experiencing, watching and witnessing. For Janie talking leads to nothing if one does not see or experience firsthand; through these final words one can know much about Janie and her silences in the novel as well as her lack of connection to the women in Eatonville and also her final reluctance to tell her story directly to Eatonville women. The force and the dynamism of Janie's telling her story to Phoebe transforms her at the end of the tale. After hearing Janie's tale Phoebe turns into a different person, one who becomes more aware of what happens around her, particularly her knowledge of the relation between herself and her husband undergoes intense change. Perhaps following Janie Phoebe says: "Lawd Ah done growed ten feet higher from jus' listenin' tuh you, Janie. Ah ain't satisfied Withmahself no mo'. Ah means tuh make Sam take me fishin' wid him after this. Nobody Better not criticize yuh in mahhearin" ( $E W G 142)$.

Through Phoebe's speech one can understand the force of Janie's visual retelling of her experience. She is totally changed by her story. Hurston tries to make this point that if black people are going to create a permanent identity for themselves they should intensely follow this traditional African form of oral sharing of their stories and experiences. If a major transformation is going to happen it is supposed to happen through the traditional and local cultural black heritage; no white is going to save black people and recognize them as independent individual. For Hurston, black identity formation and self begins within black tradition. This is a major connecting line between Hurston and Frantz Fanon. Similarly Fanon believes that black identity is definitely related to black peoples' recognition of their own cultural heritage. Janie tells Pheobe to pass on her story to the women of her community: "You can tell 'em what Ah say if you wants to. Dat's just de same as me 'cause mah tongue is in mah friend's mouf' ( $E W G 16)$.

Accordingly, an expectation is created in the reader's mind that Phoebe will retell Janie's tale, perhaps she "inspires and transforms" those women who will listen to her tale, just as Janie has inspired her, and as Daphne Lamothe puts it: “Janie's experience, her story, functions as myth for the folk, teaching them the value of selfexpression and the necessity for self-determination" (171). Janie, having returned to the surrounding, once rejected, alone in her bedroom she watches pictures of "love and light against the walls," (EWG 143) almost as though she is watching a film. She "pulls in the horizon and drapes it over her shoulder" (EWG 143) and calls in her soul to come and see. The language of this section gives us the "illusion of growth and development" (Lamothe 171). 
Therefore Hurston puts Janie on the track of "autonomy," "self-realization," and "independence" (Hubbard 37). She allows her to "wear the outfit of men which suggest power. Janie dresses in overalls, goes on the muck, and learns to shoot-even better than Tea Cake and her rebellion changes her and potentially of her friend Pheoby" (ibid). Dolan Hubbard believes that by "placing her narrative in the context of the Christian journey, itself a romance, Hurston violates readers' expectation that the protagonist should marry her black prince charming and live happily ever after" (ibid). Having returned from the horizon, Janie Crawford represents the "mature voice of experience and wisdom" (ibid).

\section{Conclusion}

This paper focused on the way Janie, the central black female character, as well as other characters such as Nanny and Joe try to make their voices be heard in a society which is dominated by White male as well as Black male norms and values. In fact, there is a great oppression in their life. In Janie's search for her identity one can see how she first struggled to overpower the ways white people considered her blackness and oppressed her. Being exposed to the fact of her own blackness for the first time in a white household, Janie became conscious of the way blackness was viewed. Because of the inner force of her character and also through her grandmother's life experience inflicted upon her by the whites Janie develops a kind of love and passion towards her blackness. By the time she grows up as an adult she becomes conscious of other inner transformations in her character through her new experiences in three successive marriages.

In the first two marriages she is still passive to a great extent, but as she moves on toward the end of her second marriage her identity takes a new form; one can see a rather fixed kind of self-realization in her. Her final speaking on the porch with Joe which brought about his severe illness and final death can be one indication that Janie is changed. In his last marriage to Tea Cake her search for identity which is accompanied by her self-protection and selfvitality leads to her decision to kill Tea Cake rather than being killed by him. Unlike her first two marriages, her decision to marry him constitutes a moment which suggests agency and activity for Janie's ever developing identity.
Deciding to live alone and returning to Eatonville rather than accepting Mrs. Proposal to her to motivate Janie to marry to one of her sons is another indication that Janie will remain single the rest of her life; this as well tells us that now Janie is alone, firm and independent.

\section{References}

[1] Balibar, Etienne. "Subjection and Subjectivation." Supposing the Subject. Joan Copjec. London: Verso, 1994.115.

[2] Bertens, Hans. Literary Theory: The Basics. London: Routledge, 2001.

[3] Bloom, Harold. Zora Neale Hurston. New York: InfoBase Publishing, 2007.

[4] Bressler, Charles. Literary Criticism: An Introduction to Theory and Practice. New York: Routledge, 1984.

[5] Descartes, Rene. Discourse on the Method and Meditation. New York: Dover Publications, 2003.

[6] Frantz, Fanon. Black Skin, White Masks. Trans. Charles Marlmann. London: Pluto P, 2008.

[7] Hubbard, Dolan. “...Ah said Ah'd Save De Text for You: Recontextualizing the Sermonto Tell (Her) story in Zora Neale Hurston's Their Eyes Were Watching God."Zora Neal Hurston. Ed. Harold Bloom. Ed. New York: InfoBase Publishing, 2007.35-50.

[8] Hurston, Zora Neale. Their Eyes Were Watching God. New York: Harper Collins,2009.

[9] Lamothe, Daphne. "Vodou Imagery, African-American Tradition and Cultural Transformation in Zora Neale Hurston's Their Eyes Were Watching God." Zora Neal Hurston. Ed. Harold Bloom. New York: InfoBase Publishing,2007.159-180.

[10] Rivkin, Julie and Michael Rayne (eds.). Literary Theory: An Anthology. Oxford: Blackwell, 2004.

[11] Tyson, Lois.Critical Theory Today. New York: Routledge, 2006.

[12] Washington, Helen Mary. "I Love The Way Janie Crawford Left Her Husband: Zora Neale Hurston's Emergent Female Hero." Zora Neal Hurston's Their Eyes Were Watching God. Ed. Harold Bloom. New York: InfoBase Publishing, 2008. 9-22. 